\title{
Beggars and Countermeasures in The City of Banda Aceh
}

\author{
Ulfia $^{1}, \mathrm{Rahmi}^{2}$ \\ \{ulfia@serambimekkah.ac.id-rahmi.ramli@serambimekkah.ac.id\} \\ ${ }^{1}$ Majoring in Accounting Economics \\ ${ }^{2}$ Serambi Mekkah University, Banda Aceh, Indonesia
}

\begin{abstract}
This study aims to find out how the life of beggars in Banda Aceh and the government's efforts to overcome the problem of beggars in Banda Aceh. This study used interview in the form of questionnaire surveys and observations field as well as some data from related agencies. The results showed that the cause of these people became beggars due to several factors that occurred in their lives. The Government has made various efforts to tackle beggars through the Social Service of Banda Aceh. Efforts that have been made by the Government of Banda Aceh for the prevention of beggars are preventive efforts, coercive efforts, rehabilitation efforts, and social reintegration efforts to prevent the appearance of more beggars.
\end{abstract}

Keywords: beggars, the causes, prevention

\section{Introduction}

Indonesia, one of the developing country has generally experience many problems in the population field. For example, high birth rates, poverty, unemployment, low levels of education of the population, health services, and low productivity. The high rate of birth leads to a higher level of population growth, with its obvious impact on the labor sector where it can be seen that job creation runs slower than the growth of the labor force, resulting in many unemployment. The Unemployment people is spread in various regions, namely in urban areas and in rural areas. The Unemployment that occurs is usually a hidden unemployment, namely the type of labor whose marginal productivity is zero or very low, so that even though working, they will not increase the level of production and become seasonal unemployment, namely unemployment that occurs at certain times [1]. If the unemployment rate is high, then the community does not have strong competitiveness so they only become spectators or become workers at the lower level.Many people become poor because they experience ignorance and continually experience systematic fatuity. Therefore, it is easy to understand that poverty can lead to ignorance, and ignorance is clearly synonymous with poverty [2] 


\section{Research Methods}

The scope of this research is to analyze the lives of beggars in Banda Aceh. To get the desired data, the researcher used several methods such as the survey by collecting data and information from the subject of this study by using an instrument in the form of a questionnaire. the questionnaire consisted of a number of questions to the respondent to be answered, besides the researcher also used interview techniques in the form of direct communication between researchers and respondents [3].

Beggars are people who earn money by begging in public places in various ways and reasons to get mercy from others (Aceh Provincial Social Service, 2015). Generally in large cities, it can often be seen beggars asking for money, food, or other objects. A few years ago, being a beggar was a situation that was forced and carried out with shame, but now it is a voluntary matter. According to Soejono Soekanto distinguishes four social problems as follows. [3]:

a. Social problems from economic factors, such as poverty and unemployment

b. Social problems of biological factors, such as infectious diseases

c. Social problems from psychological factors, such as conditions and suicide

d. Social problems from cultural factors, such as divorce and teenager delinquency.

The problem of poverty has two dimensions, namely the dimensions of income and nonincome dimensions [2]. Poverty in the income dimension is defined as poverty suffered due to the low income received, while non-income dimension poverty is characterized by the inability, lack of hope, and non-income and lack of cause. Poverty in income is easier to measure and can be divided into relative poverty and absolute poverty.

To measure poverty, BPS uses the concept of the ability to meet basic need approach. With this approach, poverty is seen as an economic inability to meet basic food and non-food needs, measured in terms of expenditure. This approach can be calculated with Head Count Index (HCI), which is the percentage of people who feel below the poverty line. There are three categories of poverty that become the major attention of the Social Affairs (2001), namely:

1. The poorest group (destitute) or often defined as poor. This group has generally has no source of income at all and does not have access to various social services.

2. The poor. This group has income below the poverty line but has relatively access to basic social services.

3. Vulnerable groups. This group can be categorized as free from poverty, because it has a relatively better life than destitute and poor groups. But actually the group that is often called "near poor" (rather poor) is still vulnerable to various social changes around it. According to [4] there are several factors that can determine the level of poverty in a community, namely:

a. Educational level

b. Type of work

c. Income level

d. Household conditions

e. Residence

f. Ownership of wealth

g. Position in the organization

h. Economic activity

According to [5] Education plays a key role in building the economy and advancing a nation, helping to absorb technology, creating sustainable growth and development. The problem caused by this lack of education is the birth of many begging people or beggars. 


\section{Results And Discussion}

Research data obtained from the Banda Aceh City Social Service contained several subdistricts which were home to beggars including in Baiturrahman sub-district, Meuraxa, Syiah Kuala, and the the sub-district Kuta Raja. According to the results of the study, the income of the beggars obtained varies greatly. This is due to the length of time begging and which areas are the goals of beggars.Basically, the income of beggars cannot meet the needs of their lives, but because they are forced to do so, this continues to be done because it is considered the easiest and does not take long to raise money. So that it needs more explicit efforts from the government to reduce the existence of these beggars. For consumption by beggars also varies. This is because the level of consumption for pure consumption needs only from the results of begging and without assistanc. Eliminating social problems such as begging is not an easy thing even though any various stimulation programs from the government will not solve the problem quickly. The cause is none other than because they enjoy the work they do without having to bother. Most of these beggars are individuals who come from groups in society who are unable to compete or compete with other humans. They choose to be a beggar who makes money from an unproductive sector.

The government also runs a development program for beggars. Community development is a "process of being" and not an "instant process" so that it takes quite a long time and tiring. So the empowerment process carried out is a series of empowerment activities carried out by facilitators in order to awaken, provide capacity, and utilize the community so that they are able to identify their own needs, organize, and manage existing resources according to their own initiative in order to meet the needs of the community and creating community welfare [6]. Banda Aceh Government through the Social Service has issued a call to the community not to serve homeless people and beggars in public places. [7]. One of the efforts of the Banda Aceh City government in curbing the beggars is by sending the Civil Service Police Unit to conduct raids in each city of Banda Aceh. The results of the raid were beggars who were netted and then handed over to the Social Service of the City of Banda Aceh to conduct rehabilitation training so that they would no longer conduct begging activities. Beggars will be taken to open houses provided by the City of Banda Aceh Social Service, there are several efforts that are as follows:
a. Preventive efforts
b. Coercive effort
c. Rehabilitation Efforts
d. Social Reintegration Efforts.

\section{Conclusions}

1. Factors that cause beggars to continue to choose a profession as a beggar include:
a. Disabilities.
b. Poor people
c. Low skills.

d. Difficult job.

2. This beggar profession is considered the easiest to make money, so the beggars continue to carry out their actions. 


\section{Suggestion}

Needs to be strict sanctions on beggars who carry out their actions as well as socialization to the community to channel alms to places that should not spoil the beggars.

\section{References}

[1] S. Sukirno, Macroeconomics. Jakarta: Raja Grafindo Persada, 2013.

[2] Winardi, Economic Development. Jakarta: Gramedia, 2010.

[3] K. Maryati and J. Suryawati, Sociology. Jakarta: Erlangga, 2016.

[4] P. Wirutomo, Indonesian social system. Jakarta: University of Indonesia, 2012.

[5] S. C. S. Todaro, Michael P., Economic Development, 11th ed. United Kingdom: Arragement with Pearson Education Limited, 2011.

[6] A. Muslim, The Basics of Community Development. Yogyakarta: Samudra Baru, 2012.

[7] S. Indonesia, "Banda Aceh issued a call not to serve beggars in public places," Aceh.Tribunnews, Banda Aceh, Aug-2016.

[1] S. Sukirno, Macroeconomics. Jakarta: Raja Grafindo Persada, 2013.

[2] Winardi, Economic Development. Jakarta: Gramedia, 2010.

[3] K. Maryati and J. Suryawati, Sociology. Jakarta: Erlangga, 2016.

[4] P. Wirutomo, Indonesian social system. Jakarta: University of Indonesia, 2012.

[5] S. C. S. Todaro, Michael P., Economic Development, 11th ed. United Kingdom: Arragement with Pearson Education Limited, 2011.

[6] A. Muslim, The Basics of Community Development. Yogyakarta: Samudra Baru, 2012.

[7] S. Indonesia, "Banda Aceh issued a call not to serve beggars in public places," Aceh.Tribunnews, Banda Aceh, Aug-2016. 